\section{Structure of the retinoblastoma protein bound to adenovirus E1A reveals the molecular basis for viral oncoprotein inactivation of a tumor suppressor}

\author{
Xin Liu and Ronen Marmorstein ${ }^{1}$ \\ Program in Gene Expression and Regulation, The Wistar \\ Institute, Philadelphia, Pennsylvania 19104, USA; \\ and Department of Chemistry, University of Pennsylvania, \\ Philadelphia, Pennsylvania 19104, USA
}

The adenovirus (Ad) E1A (Ad-E1A) oncoprotein mediates cell transformation, in part, by displacing E2F transcription factors from the retinoblastoma protein $(\mathrm{pRb})$ tumor suppressor. In this study we determined the crystal structure of the $\mathrm{pRb}$ pocket domain in complex with conserved region 1 (CR1) of Ad5-E1A. The structure and accompanying biochemical studies reveal that E1A-CR1 binds at the interface of the $A$ and $B$ cyclin folds of the $\mathrm{pRb}$ pocket domain, and that both E1A-CR1 and the E2F transactivation domain use similar conserved nonpolar residues to engage overlapping sites on $\mathrm{pRb}$, implicating a novel molecular mechanism for $\mathrm{pRb}$ inactivation by a viral oncoprotein.

Supplemental material is available at http://www.genesdev.org.

Received July 5, 2007; revised version accepted September 6, 2007.

The retinoblastoma protein $(\mathrm{pRb})$ functions as a principle checkpoint protein of the G1-S cell cycle transition. Loss-of-function mutations and other genetic alterations effecting $\mathrm{pRb}$ function are frequently found in human cancer. pRb, also known as p105, belongs to a functionally related nuclear pocket protein family including two other members, p107 and p130, which share significant sequence homology with $\mathrm{pRb}$ in the large pocket region encompassing the $\mathrm{A}$ and $\mathrm{B}$ cyclin fold domains and $\mathrm{C}$-terminal region of $\mathrm{pRb}$.

$\mathrm{pRb}$ and its orthologs inhibit G1-S cell cycle progression by binding and repressing the transcriptional activation activity of E2F transcription factors. The mechanism of $\mathrm{pRb}$-mediated transcription inhibition has been a subject of extensive study. The picture that has emerged is that $\mathrm{pRb}$ binds to and sequesters E2F transcription factors by interacting primarily with two regions on E2F, the transactivation (TA) domain and the marked box (MB) domain. Structural studies reveal that while $\mathrm{pRb}$ binds to E2F-TA through a cleft between the $\mathrm{A}$ and $\mathrm{B}$ cyclin folds of the $\mathrm{pRb}$ pocket domain (Lee et al.

[Keywords: Retinoblastoma protein; viral oncoprotein; adenovirus E1A; tumor suppressor; pRb/E1A complex]

${ }^{1}$ Corresponding author.

E-MAIL marmor@wistar.org; FAX (215) 898-0381.

Article is online at http://www.genesdev.org/cgi/doi/10.1101/gad.1590607.
2002; Xiao et al. 2003), the C-terminal domain of $\mathrm{pRb}$ interacts with the $\mathrm{MB}$ domains of an E2F/DP heterodimer (Helin et al. 1992; Dyson 1998; Lee et al. 2002; Dick and Dyson 2003; Xiao et al. 2003; Rubin et al. 2005). The pRb/E2F-DP complex is also capable of recruiting histone deacetylases (HDACs) to E2F promoter regions for transcriptional repression (Harbour and Dean 2000).

$\mathrm{pRb}$ is a common target of viral oncoproteins, including adenovirus (Ad) E1A, human papillomavirus (HPV) E7, and simian virus 40 (SV40) large T antigen (LTa). These small DNA viruses usurp the DNA replication machinery of host cells to achieve viral genome replication by prematurely stimulating cell cycle S-phase entry, leading to the aberrant dissociation of the E2F transcription factors from $\mathrm{pRb}$ with subsequent transcriptional activation of E2F-regulated S-phase genes (Liu and Marmorstein 2006).

As a versatile regulatory viral protein, Ad-E1A is able to interact with numerous cellular factors including the pRb pocket proteins (Whyte et al. 1988; Ewen et al. 1991; Li et al. 1993), and other transcription factors including p300/CBP (Arany et al. 1995), CtBP (Schaeper et al. 1995), SWI2/SNF2-related p400 (Fuchs et al. 2001), and the Sur2 component of the mediator complex (Boyer et al. 1999). Human adenoviruses can be grouped into six classes, and E1A proteins of serotypes 2/5 and 12 from classes $\mathrm{C}$ and $\mathrm{A}$, respectively, are the most well studied (Fig. 1A). Ad-E1A shares limited sequence homology with HPV-E7 and SV40-LTa within a strictly conserved LxCxE motif that mediates high-affinity binding to $\mathrm{pRb}$. The structure of the $\mathrm{pRb}$ pocket domain bound to a LxCxE-containing peptide from HPV-E7 reveals that the LxCxE sequence binds within a shallow groove on the $\mathrm{B}$ domain of the pocket (Lee et al. 1998). Biochemical and structural studies suggest that while conserved region 3 (CR3) of HPV-E7 competes for a portion of the pRb Cterminal region that partially overlaps with one of the bipartite binding sites for the E2F/DP heterodimer, leading to E2F displacement (Kim et al. 2001; Rubin et al. 2005; Liu et al. 2006), the LTa of SV40 uses an ATPdependent molecular chaperon mechanism to dissemble pRb/E2F complexes (Kim et al. 2001).

Adenovirus E1A appears to disrupt $\mathrm{pRb} / \mathrm{E} 2 \mathrm{~F}$ complexes through a mechanism that differs from HPV-E7 and SV40-LTa. In particular, biochemical studies reveal that the $\mathrm{N}$-terminal CR1 domain of E1A mediates E2F displacement in a competitive manner (Fattaey et al. 1993; Ikeda and Nevins 1993). In order to determine the mechanistic basis for how Ad-E1A mediates the disruption of $\mathrm{pRb} / \mathrm{E} 2 \mathrm{~F}$ complexes, we determined the X-ray crystal structure of the $\mathrm{pRb}$ pocket domain in complex with the CR1 region of Ad-E1A. The structure and complementary biochemical studies reveal that the CR1 region of Ad-E1A and the TA domain of E2F use analogous residues to directly compete for the same binding site on $\mathrm{pRb}$, implicating a novel molecular mechanism for $\mathrm{pRb}$ inactivation by a viral oncoprotein.

\section{Results and Discussion}

Overall structure of the $\mathrm{pRb} / \mathrm{E} 1 \mathrm{~A}$ complex

The CR1 domain of E1A was defined by sequence alignments from different serotypes to span residues $42-72$ of 

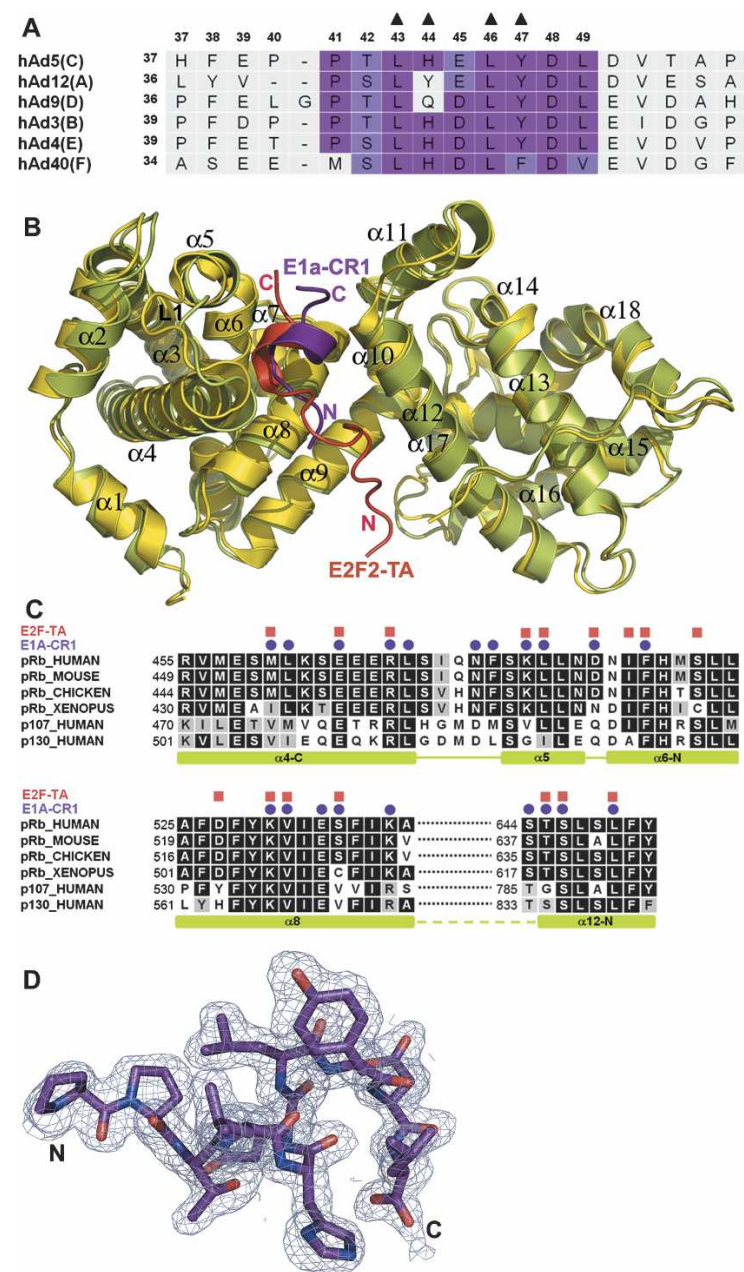

Figure 1. Overall structure of the $\mathrm{pRb} / \mathrm{E} 1 \mathrm{~A}$ complex. $(A)$ Sequence alignment of E1A-CR1 from different adenovirus serotypes. The invariant and conserved E1A-CR1 residues are highlighted in dark and light purple, respectively. Residues indicated by solid triangles are involved in $\mathrm{pRb}$ interaction. $(B)$ Structural alignment of $\mathrm{pRb} / \mathrm{E} 1 \mathrm{~A}$ CR1 and pRb/E2F2-TA with E1A-CR1 and E2F2-TA are shown in purple and red, respectively. $(C)$ Sequence alignment among human $\mathrm{pRb}$ paralogs and $\mathrm{pRb}$ orthologs from selected species. Residues that mediate interaction with E1A-CR1 and E2F-TA are marked with purple circles and red squares, respectively. (D) Blow-up view of a stick model of the E1A-CR1 peptide modeled into a composite omit density map contoured to $1.5 \mathrm{\sigma}$.

serotype 5 adenovirus E1A (Ad5-E1A) (Avvakumov et al. 2004). This region harbors distinct nonoverlapping binding sites for $\mathrm{pRb}$ and $\mathrm{p} 300 / \mathrm{CBP}$ (Wang et al. 1993). The boundary for $\mathrm{p} 300 / \mathrm{CBP}$ binding within CR1 was previously determined to start around residue 50 (Loewenstein et al. 2006), thus implicating residues 42-49 for $\mathrm{pRb}$ binding. Consistent with this, a peptide encompassing residues 37-49 of Ad5-E1A was shown to be necessary and sufficient to disrupt pRb/E2F complexes (Dyson et al. 1992; Fattaey et al. 1993; Ikeda and Nevins 1993). Based on this data, a peptide encoding residues 37-49 of Ad5-E1A (Fig. 1A) was used for cocrystallization with the $\mathrm{pRb}$ pocket domain (residues $380-787$ harboring an internal loop deletion of residues 582-642). Crystals of the complex were obtained in spacegroup $\mathrm{P}_{1}$ and the structure was determined with molecular replacement using the $\mathrm{pRb}$ core domain chain A of PDB entry $1 \mathrm{~N} 4 \mathrm{M}$ as the search model.

The structure of the $\mathrm{pRb}$ pocket domain is essentially superimposable with other reported $\mathrm{pRb}$ pocket domains in various liganded complexes (Lee et al. 1998, 2002; Kim et al. 2001; Xiao et al. 2003). The E1A-CR1 peptide binds within a deep groove at the interface of the $\mathrm{A}$ and $\mathrm{B}$ cyclin fold regions of the $\mathrm{pRb}$ pocket domain, largely formed by helices $\alpha 4, \alpha 5, \alpha 6, \alpha 8$, and $\alpha 11$ of the pRb pocket domain (Fig. 1B). This contacted surface of $\mathrm{pRb}$ is highly conserved within the $\mathrm{pRb}$ pocket proteins (Fig. 1C). This conservation argues for a conserved and common mechanism of E1A CR1 domain binding to the family of $\mathrm{pRb}$ pocket proteins. Like in the binding of E2F-TA to $\mathrm{pRb}$ (Lee et al. 1998), binding of E1A-CR1 to $\mathrm{pRb}$ increases the ordering of the connecting loop, L1, between the $\alpha 4$ and $\alpha 5$ helices of $\mathrm{pRb}$ (Fig. 1B). Ten of 13 residues of the E1A-CR1 peptide are well ordered in the structure of the complex (Fig. 1D) and harbor the nine most highly conserved residues of the E1A-CR1 peptide (residues 4149) (Fig. 1A). Residues 43-47 of the E1A-CR1 peptide form a short one-turn $\alpha$ helix, and flanking residues form extended loops. Together, binding of this E1A-CR1 peptide to the $\mathrm{pRb}$ pocket domain buries a total solvent accessible area of $1623 \AA^{2}$.

Intriguingly, similar to the crystals of the $\mathrm{pRb} / \mathrm{E} 2 \mathrm{~F}-\mathrm{TA}$ complex (PDB entry 1N4M) (Lee et al. 2002), there are two $\mathrm{pRb}$ molecules and three peptides in one asymmetric unit of the crystal lattice, with the extra copy of E1ACR1 loosely bound to a shallow groove on the side of the B domain, which overlaps with the binding site for the LxCxE peptide of HPV-E7 (Lee et al. 1998, 2002). The residues of E2F-TA and E1A-CR1 that are engaged in $\mathrm{pRb}$ binding at the B domain diverge significantly from the more extensively bound $\mathrm{LxCxE}$ peptide, although two common residues, Y756 and N757, from $\mathrm{pRb}$ form hydrogen bonds with the main-chain atoms of each of the peptides, implicating that this site of $\mathrm{pRb}$ may be involved in binding to other proteins as suggested previously (Lee et al. 2002).

\section{Structural comparison with the $p R b / E 2 F$ complex and molecular determinants for $p R b / E 1 A-C R 1$ interaction}

A structural alignment of the $\mathrm{pRb} / \mathrm{E} 1 \mathrm{~A}-\mathrm{CR} 1$ complex with the structure of $\mathrm{pRb}$ bound to the TA peptide of E2F (PDB entry $1 \mathrm{~N} 4 \mathrm{M}$ ) reveals that the two peptides bind to overlapping binding sites on $\mathrm{pRb}$ (Fig. 1B). In analyzing the structural determinants for E1A-CR1 binding to $\mathrm{pRb}$, three highly conserved hydrophobic residues, L43, L46, and Y47 can be aligned with similar residues of E2F-TA, I422, L425, and F426, and the corresponding residues occupy a similar hydrophobic pocket on the $\mathrm{pRb}$ surface (Figs. 1B, 2A). In contrast, an E1A-CR1-specific and semiconserved $\mathrm{H} 44$ residue (Fig. 2C) mediates a hydrogenbonding network with both the main chain and side chain of residues E464 and N472 from the $\alpha 4$ helix and L1 loop of pRb, respectively (Fig. 2B). Strikingly, N472 of $\mathrm{pRb}$ in the E2F complex points away from the binding groove, but moves $\sim 8 \AA$ toward the binding groove of the E1A complex to make a hydrogen bond with the H44 side chain of E1A. The carboxyl oxygen of the E464 side chain of $\mathrm{pRb}$ also makes three hydrogen bonds with the H44 side chain, main chain, and L43 main chain of E1A, respectively. The main-chain oxygen of P40 of E1A also 

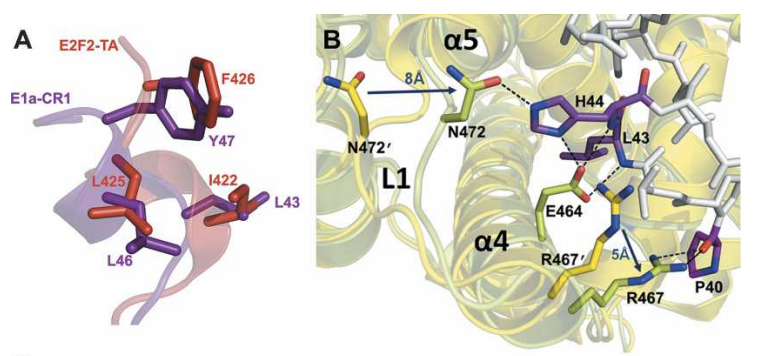

C

E1A 37 H F E P P T D H E

E2F2 416 L E E A G E E I S D L F D S

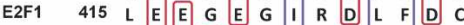

Orf22 94 L E D D D L N V A G V V F F V

Figure 2. Comparison between $p R b / E 1 A-C R 1$ and $p R b / E 2 F-T A$ complexes. (A) Close-up view of the structural alignment of E1ACR1 and E2F2-TA with the three conserved hydrophobic residues highlighted in stick representation. (B) Close-up view of the hydrogen-bonding network between E1A-CR1 and the $\mathrm{pRb}$ pocket domain. Prominent residue movement incurred by E1A-CR1 binding, as compared with E2F2-TA, is indicated by arrows. (C) Structurebased sequence alignment between E1A-CR1, E2F-TA including E2F1-TA and E2F2-TA, and Orf22 from CELO virus.

makes two additional hydrogen bonds with the R467 guanidinium group of $\mathrm{pRb}$. This arginine residue is shifted by $\sim 5 \AA$ relative to its position in the E2F complex. Notably, the side chain and main chain of E45 forms an intramolecular hydrogen bond with both the main-chain and side-chain atoms of T42 that appears important for the formation of the short $\alpha$ helical secondary structure within the middle of the E1A-CR1 peptide (Supplementary Fig. S1). Finally, hydrophobic residues at both ends of the E1A-CR1 peptide, including P40 and P41 on the N-terminal end and L49 on the C-terminal end, are also involved in van der Waals interactions with $\mathrm{pRb}$.

Using the structurally aligned hydrophobic residues L43, L46, and Y47 of E1A-CR1 as anchors, the primary sequence of E1A-CR1 can be aligned with E2F-TA (Fig. $2 \mathrm{C})$, which reveals additional sequence conservation between the E1A-CR1 and E2F-TA peptides. In particular, residues E45 and D48 of E1A-CR1 can be aligned with residues D424 and D427 of E2F-TA. These acidic residues are not structurally aligned; however, this sequence conservation may reflect another shared cellular target of the E2F and E1A proteins.

\section{Mutational analysis of the $p R b-E 1 A$ interface}

To dissect the functional contribution of different $\mathrm{pRb}-$ E1A-binding determinants, we carried out solution-binding studies of selected E1A-CR1 mutants using both GST pull-down and isothermal titration calorimetry (ITC).

As shown in Figure 3A, GST-pRb (residues 376-787) harboring the $\mathrm{A}$ and $\mathrm{B}$ domains of the $\mathrm{pRb}$ pocket domain stoichiometrically pulls down E1A-CR1CR2CR3 (residues 36-189) and E1A-CR1CR2 (residues 37-140) as positive controls. To specifically assay the contribution of CR1 residues for $\mathrm{pRb}$ interaction, we used a CR2-deleted E1A construct, E1A-CR1-linker (residues 37-121). Using this protein construct, we show that $\mathrm{pRb}$ specifically pulls down E1A-CR1-linker (residues 37-121) and the corresponding H44Y and L46A mutants, although the mutants show impaired $\mathrm{pRb}$ binding. Other
CR1 mutants including L43A, H44A, H44Q, L47G, and L47R fail to interact with $\mathrm{pRb}$ under these assay conditions (Fig. 3A). H44Y and H44Q mutants were designed to mimic the naturally occurring variations at this position in E1A proteins from other serotypes (Fig. 1C).

The GST pull-down results described above were con-

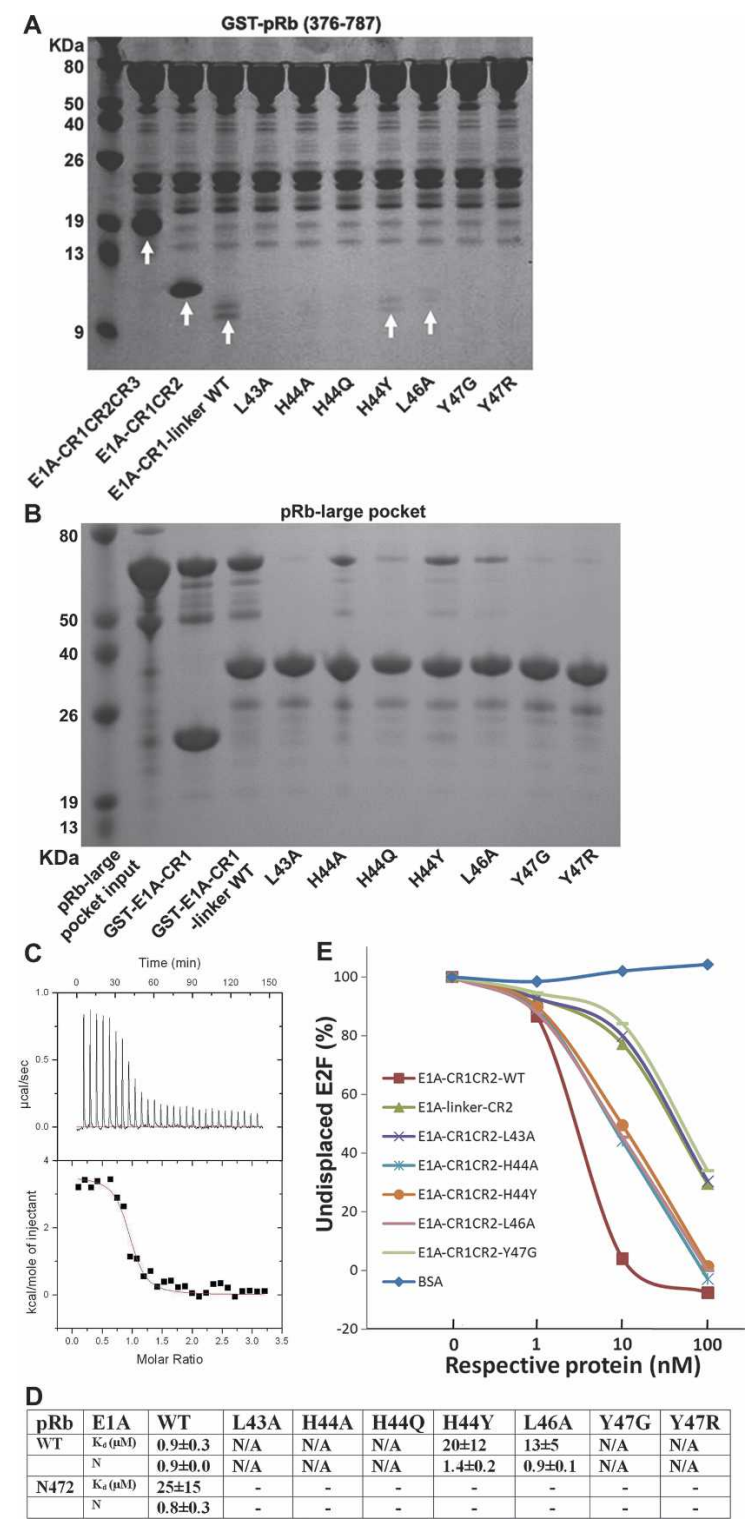

Figure 3. pRb-E1A-CR1-binding analysis and E2F displacement assay. (A) GST pull-down experiments using GST-pRb pocket domain and untagged E1A proteins. The GST-pRb pocket domain runs at $\sim 80 \mathrm{kDa}$, and white arrows point to the different E1A protein constructs that are pulled down by GST-pRb. (B) Reciprocal GST pulldown using GST-E1A-CR1 (residues 37-49) and GST-E1A-CR1linker (residues 37-121) proteins. His-tagged pRb large pocket (residues $376-928$ ) that is pulled down runs at $\sim 65 \mathrm{kDa}$. (C) ITC profiles for wild-type E1A-CR1-linker (residue 37-121) titrated into wildtype $\mathrm{pRb}$ (residues 380-787 with an internal loop deletion of residues 582-642). (D) Binding affinity data of E1A-CR1 wild type and mutants for the $\mathrm{pRb}$ pocket domain as measured by ITC. (N/A) Binding is too weak to fit properly $\left(\mathrm{K}_{\mathrm{d}}>100 \mu \mathrm{M}\right) ;(-)$ experiments were not performed. (E) Results from a microtiter plate ELISA assay are shown where the concentration of different E1A protein constructs (indicated) is plotted against the amount of undisplaced E2F remaining bound to $\mathrm{pRb}$. 
firmed using reciprocal GST pull-down experiments using GST-E1A proteins. As shown in Figure 3B, both wildtype GST-E1A-CR1 harboring only the minimal binding residues 37-49 of E1A and wild-type GST-E1A-linker efficiently pull down $\sim 20 \%$ of input His-tagged $\mathrm{pRb}$ (residues 376-928 or large pocket). In contrast, the L43A, Y47G, and Y47R mutants completely abolish pRb-binding activity, and mutations on H44 and L46 impair pRbbinding activity.

To obtain more quantitative information on $\mathrm{pRb}$ binding by E1A-CR1, we used ITC experiments with an E1ACR1-linker (residues 37-121) construct. As can be seen in Figure 3, C and D, the E1A-CR1-linker binds the $\mathrm{pRb}$ core domain with a disassociation constant of $\sim 1 \mu \mathrm{M}$ and with a stoichiometry of $1: 1$. The binding is endothermic, consistent with the largely hydrophobic nature of the $\mathrm{pRb}-\mathrm{E} 1 \mathrm{~A}-\mathrm{CR} 1$ interface that is observed in the crystal structure of the complex.

Of the three hydrophobic anchor residues that appear to play a particularly important role in stabilizing the pRb-E1A-CR1 interface, residues L43 and Y47 appear to be indispensable for $\mathrm{pRb}$ binding, as mutation of these residues completely abolishes $\mathrm{pRb}$ binding under the ITC condition, while the L46A E1A mutant decreases pRb-binding affinity by $\sim 10$-fold (Fig. 3D). Given the extensive $\mathrm{pRb}$ interactions that are mediated by $\mathrm{H} 44$ of E1A-CR1, we also assessed the effect of mutating H44. As shown in Figure 3D, all H44 mutants are defective in $\mathrm{pRb}$ binding and mutation of a $\mathrm{H} 44$-contacting residue in pRb, N472A (Fig. 2B), shows a 20 -fold reduction in binding affinity for E1A-CR1 (Fig. 3D).

\section{Mutational analysis for E1A-CR1-mediated E2F displacement activity from $p R b$}

Having established the functional importance of specific structural determinants for E1A-CR1 binding to $\mathrm{pRb}$, we next assessed their importance for disruption of $\mathrm{pRb} / \mathrm{E} 2 \mathrm{~F}$ complexes utilizing an ELISA-based $\mathrm{pRb}-\mathrm{E} 2 \mathrm{~F}$ displacement assay that measures the amount of undisplaced E2F remaining bound to $\mathrm{pRb}$. In control experiments, we first established the relative importance of the CR1 and CR2 domains of E1A for disruption of $\mathrm{pRb} / \mathrm{E} 2 \mathrm{~F}$ complexes. As shown in Figure 3E, the wild-type E1ACR1CR2 (residues 37-140) construct shows robust E2F displacement activity, even at a concentration of E1ACR1CR2 close to $1 \mathrm{nM}$. Deletion of the high-affinity $\mathrm{pRb}$-binding LxCxE-containing CR2 region of E1A severely compromises displacement activity, as a significant amount of E2F displacement is only observed at 1 $\mu \mathrm{M}$ of the E1A-CR1-linker construct (data not shown). Interestingly, deletion of the entire CR1 domain of E1A does not deplete all of the E2F displacement activity in this assay, and significant E2F displacement is observed at an E1A-linker-CR2 (residues 50-140) concentration of $100 \mathrm{nM}$, a 100-fold higher concentration than required for the E1A-CR1CR2 (residues 37-140) construct. These results suggest that both the $\mathrm{CR} 1$ and $\mathrm{CR} 2$ regions of E1A contribute to disruption of $\mathrm{pRb} / \mathrm{E} 2 \mathrm{~F}$ complexes.

In the context of the E1A-CR1CR2 (residues 37-140) protein construct, several single mutants within the CR1 region of E1A were analyzed for E2F displacement activity (Fig. 3E). The results of these studies reveal that these mutants can be grouped into two categories based on their potency of displacing E2F from $\mathrm{pRb}$. While the L43A and Y47G E1A mutants display impaired displace- ment activity, comparable with the CR1 deletion mutant, H44A, H44Y, and L46A have a milder effect on displacement activity. Taking this data together with the $\mathrm{pRb} / \mathrm{E} 1 \mathrm{~A}-\mathrm{CR} 1-$ binding studies described above, we concluded that L43, Y47, and, to a lesser extent, L46 and $\mathrm{H} 44$ of the E1A-CR1 region play key roles in both $\mathrm{pRb}$ binding and E2F displacement.

\section{Correlation with previous functional studies}

The structure of the pRb/E1A-CR1 complex described here presents a molecular picture for $\mathrm{pRb}$ interaction with E1A-CR1 and E1A-CR1-mediated E2F displacement from $\mathrm{pRb}$. These studies correlate well with functional studies that have been reported over the past two decades, as summarized below.

The involvement of E1A-CR1 in pRb binding has been underscored in several previous studies using E1A constructs harboring full or partial CR1 deletions or E1ACR1 peptides (Egan et al. 1988; Dyson et al. 1992; Fattaey et al. 1993; Ikeda and Nevins 1993; Wong and Ziff 1994). We also observed significant binding affinity of E1A-CR1 to $\mathrm{pRb}$ with an apparent dissociation constant of $\sim 1 \mu \mathrm{M}$. Moreover, the E1A-CR1 and E2F-TA-binding sites on $\mathrm{pRb}$ had been previously suggested to be overlapping based on peptide competition assays (Fattaey et al. 1993). Here we show that E1A-CR1 structurally resembles one of the bipartite pRb-binding sequences of E2F-TA and occupies an overlapping site within the interface of $\mathrm{A}$ and $\mathrm{B}$ cyclin folds of the $\mathrm{pRb}$ pocket domain (Lee et al. 2002; Xiao et al. 2003).

The importance of residue Y47 of E1A-CR1 that overlaps with a corresponding residue of E2F has been highlighted in previous studies, showing that mutation of this residue confers a significant $\mathrm{pRb}$-binding defect both in vitro and in vivo (Wang et al. 1993). We further identified and tested two other hydrophobic residues of E1A-CR1, L43, and L46, to be additional molecular determinants for $\mathrm{pRb}$ binding. In addition, we found that an E1A unique semiconserved residue $\mathrm{H} 44$ is critical for $\mathrm{pRb}$ binding as well. Naturally occurring variants in this position in E1A proteins from different adenovirus serotypes appear to affect both $\mathrm{pRb}$ binding and E2F displacement activity. An H44Y mutant, mimicking the CR1 domain of Ad12-E1A, is defective in both $\mathrm{pRb}$ binding (by 20-fold) and E2F displacement compared with the wild-type counterpart (Fig. 3D,E). Interestingly, Ad12E1A has been shown to be less potent in transforming primary BRK cells than Ad2-E1A, and this difference has been previously mapped to the CR1 domain (Leclere et al. 1993). Like Ad5-E1A, Ad2-E1A also contains a histidine at position 44. Based on this observation, we hypothesize that this variation may correlate with the different transforming abilities of different adenovirus serotypes.

Sequence homology between E1A-CR1 and E2F-TA has been noted previously (Trouche and Kouzarides 1996); however, this sequence homology is not compatible with the structural homology used for analogous $\mathrm{pRb}$ binding by these proteins. We provided a structurebased sequence alignment using E1A residues L43, L46, and Y47 as anchors, and it correlates with a functional meaning of "viral mimicry" both in primary sequence and spatial arrangement defining an L/I-X-X-L-Y/F motif for E2F-TA displacement from pRb (Figs. 2C, 4). We propose that other proteins containing such a motif hold the 


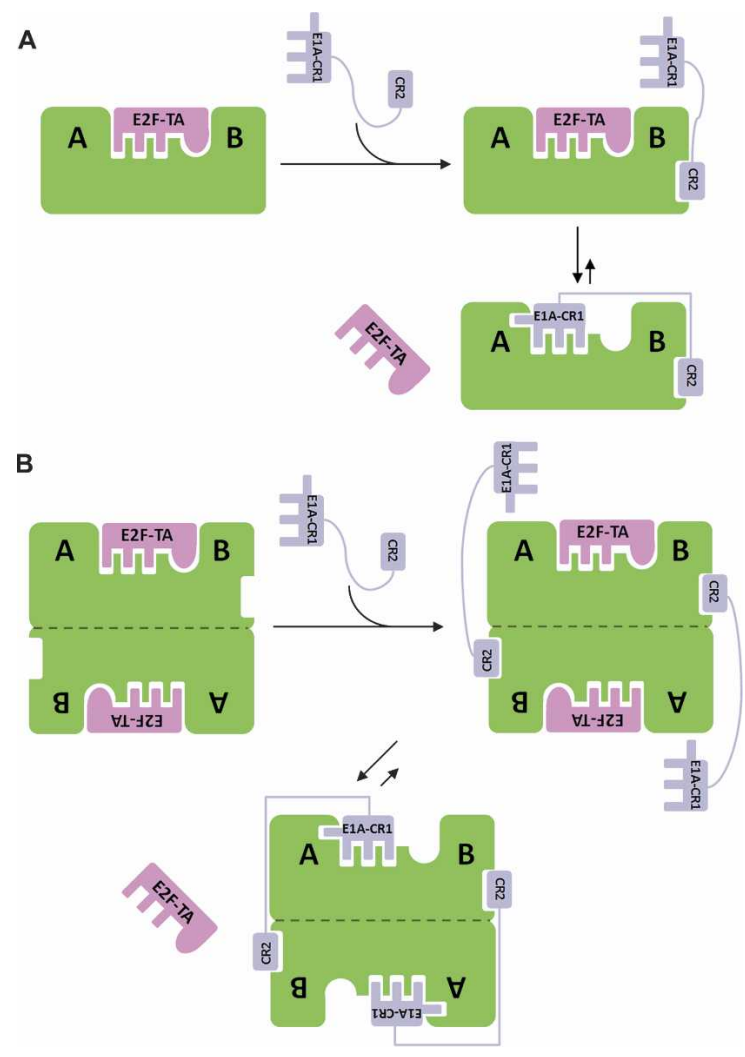

Figure 4. Schematic models for E2F-TA displacement from $\mathrm{pRb}$ by E1A. $(A, B)$ Two alternative models are illustrated, with $\mathrm{pRb}$ shown in bright green, E1A including CR1 and CR2 domains shown in light purple, and E2F-TA shown in red.

potential for disrupting $\mathrm{pRb} / \mathrm{E} 2 \mathrm{~F}$ complexes through a similar mechanism. Correlating with this possibility, a 17-residue peptide from a functional E1A homolog, Orf22, of chicken embryo-lethal orphan (CELO) virus has been shown to bind to the $\mathrm{pRb}$ pocket domain to mediate E2F displacement (Lehrmann and Cotten 1999). Intriguingly, we find one close variation of the L/I-x-XL-Y/F motif within the 17-residue peptide from Orf22 (Fig. 2C), which possibly further expands this motif to $\mathrm{L} / \mathrm{I} / \mathrm{V}-\mathrm{x}-\mathrm{x}-\mathrm{L} / \mathrm{V}-\mathrm{Y} / \mathrm{F}$. Interestingly, such direct tumor suppressor-inactivating properties by viral mimicry has also been suggested for SV40-LTa, which mimics DNA to directly block the DNA-binding site on p53 (Lilyestrom et al. 2006).

The functional role played by E1A-CR1 in E2F displacement has been previously described (Raychaudhuri et al. 1991; Fattaey et al. 1993; Ikeda and Nevins 1993; Kim et al. 2001). The structural information provided in this study now allows us to extend these earlier findings to the molecular level. Our studies reveal a mode of direct competition between E1A-CR1 and E2F-TA that diverges significantly from the mechanism of $\mathrm{pRb}$ inactivation by the HPV-E7 and SV40-LTa viral oncoproteins. Interestingly, although E1A protein constructs harboring both the CR1 and CR2 regions disrupt $\mathrm{pRb} / \mathrm{E} 2 \mathrm{~F}$ complexes in the 1-10 nM range of E1A protein, we also observe significant E2F displacement activity for E1A protein constructs in the $100-\mathrm{nM}$ range that lack the entire CR1 domain. This result is not unexpected, since the linker region connecting CR1 to CR2 may exert a nonspecific steric barrier for E2F binding to the $\mathrm{pRb}$ pocket domain. The presence of an intact CR1 domain therefore potentiates the E2F displacement activity of E1A to the 1-10 $\mathrm{nM}$ concentration range, which may reflect the physiological concentration of E1A in vivo.

\section{Model for Ad-E1A disruption of $p R b / E 2 F$ complexes}

Taking the present structure together with a previously reported $\mathrm{pRb} / \mathrm{HPV}-\mathrm{E} 7-\mathrm{CR} 2$ complex suggests that the CR1 and CR2 regions of E1A work together to achieve maximal E2F displacement activity. In particular, the binding sites for CR1 and CR2 on the $\mathrm{pRb}$ pocket domain are $\sim 30 \AA$ apart, and a long flexible linker between CR1 and CR2 is apparently required to have both domains function in synergy to displace E2F through an intramolecular displacement mechanism that is depicted in Figure 4A. Alternatively, it is formally possible that the $\mathrm{CR} 2$ region of $\mathrm{E} 1 \mathrm{~A}$ might bind one $\mathrm{pRb}$ molecule, while the CR 1 domain of the same E1A molecule might bind a second $\mathrm{pRb}$ molecule of a $\mathrm{pRb}$ oligomer to displace $\mathrm{E} 2 \mathrm{~F}$ through an intermolecular mechanism. Although there is no direct evidence for such a mechanism, the presence of $\mathrm{pRb}$ oligomers has been suggested previously (Fig. 4B; Hensey et al. 1994). In conclusion, the structure of the $\mathrm{pRb} / \mathrm{E} 1 \mathrm{~A}$ complex with the associated biochemical studies reported here provides a molecular basis for understanding how the $\mathrm{pRb}$ tumor suppressor is inactivated by the adenovirus E1A protein and paves the way for the structure-based design of compounds to antagonize the ability of E1A and other viral oncoproteins to mediate cell transformation.

\section{Materials and methods}

Crystallization and structure determination

The pRb central pocket and adenovirus E1A-CR1 domains were overexpressed in bacteria as N-terminal GST fusion proteins and were purified and concentrated as described in the Supplemental Material. Crystals were obtained by mixing E1A-CR1 peptide with $\mathrm{pRb}$ in a 2:1 ratio to a final concentration of $15 \mathrm{mg} / \mathrm{mL}$ for the $\mathrm{pRb} / \mathrm{E} 1 \mathrm{~A}-\mathrm{CR} 1$ complex using the hanging drop vapor diffusion method from a solution containing $15 \mathrm{mM}$ magnesium acetate tetrahydrate, $50 \mathrm{mM}$ sodium cacodylate trihydrate (pH 6.0), and 1.7 M ammonium sulfate. The structure was solved by molecular replacement using chain A of pdb entry 1N4M as the search model and refined as described in the Supplemental Material. The final refined model contains two $\mathrm{pRb}$ molecules and three E1A-CR1 peptides (Supplementary Table S1).

Pull-down and ITC-binding assays

GST pull-down studies were carried out as described in the Supplemental Material. Briefly, GST-tagged proteins were mixed with pre-equilibrated glutathione-Sepharose 4B beads and either untagged E1A or His-tagged $\mathrm{pRb}$ was added and incubated for $1 \mathrm{~h}$ at $4^{\circ} \mathrm{C}$. The bound protein samples were resolved by SDS-PAGE.

ITC studies were carried out as described in the Supplemental Material. Briefly, purified E1A-CR1-linker (residues 37-121) wild type and mutants as the titrant at a concentration of 600-800 $\mu \mathrm{M}$ were titrated into a reaction chamber containing the loop-deleted central pocket domain of $\mathrm{pRb}$ at a concentration of $40-50 \mu \mathrm{M}$ at $15^{\circ} \mathrm{C}$. A nonlinear fit of the data was generated to calculate both the binding stoichiometry and the dissociation constant.

In vitro E2F displacement ELISA assay

An ELISA-based microtiter plate assay was developed to assess the ability of E1A protein constructs to displace E2F from pRb (see Supplemental Material). Briefly, preformed GST-pRb/E2F1 complex was mixed with increasing concentrations of E1A, incubated, and added to a glutathionecoated 96-well microtiter plate. Plates were then washed and anti-E2F1 
monoclonal antibody was added to detect the remaining E2F1 bound to GST-pRb on the plate after displacement.

\section{Acknowledgments}

We thank S.J. Gamblin for providing the expression clone for the E2F1(243-437) protein. This work was supported by an NIH grant to R.M. (CA094165) and a grant from the Commonwealth Universal Research Enhancement Program, Pennsylvania Department of Health awarded to the Wistar Institute. Coordinates for the pRb/E1A-CR1 complex structure have been deposited to the Rutgers Collaborative Structural Bioinformatics database under accession number $2 \mathrm{R} 7 \mathrm{G}$

\section{References}

Arany, Z., Newsome, D., Oldread, E., Livingston, D.M., and Eckner, R. 1995. A family of transcriptional adaptor proteins targeted by the E1A oncoprotein. Nature 374: 81-84.

Avvakumov, N., Kajon, A.E., Hoeben, R.C., and Mymryk, J.S. 2004. Comprehensive sequence analysis of the E1A proteins of human and simian adenoviruses. Virology 329: 477-492.

Boyer, T.G., Martin, M.E., Lees, E., Ricciardi, R.P., and Berk, A.J. 1999. Mammalian Srb/Mediator complex is targeted by adenovirus E1A protein. Nature 399: 276-279.

Dick, F.A. and Dyson, N. 2003. pRB contains an E2F1-specific binding domain that allows E2F1-induced apoptosis to be regulated separately from other E2F activities. Mol. Cell 12: 639-649.

Dyson, N. 1998. The regulation of E2F by pRB-family proteins. Genes \& Dev. 12: 2245-2262.

Dyson, N., Guida, P., McCall, C., and Harlow, E. 1992. Adenovirus E1A makes two distinct contacts with the retinoblastoma protein. J. Virol. 66: 4606-4611.

Egan, C., Jelsma, T.N., Howe, J.A., Bayley, S.T., Ferguson, B., and Branton, P.E. 1988. Mapping of cellular protein-binding sites on the products of early-region 1A of human adenovirus type 5. Mol. Cell. Biol. 8: 3955-3959.

Ewen, M.E., Xing, Y.G., Lawrence, J.B., and Livingston, D.M. 1991. Molecular cloning, chromosomal mapping, and expression of the cDNA for p107, a retinoblastoma gene product-related protein. Cell 66: $1155-1164$.

Fattaey, A.R., Harlow, E., and Helin, K. 1993. Independent regions of adenovirus E1A are required for binding to and dissociation of E2Fprotein complexes. Mol. Cell. Biol. 13: 7267-7277.

Fuchs, M., Gerber, J., Drapkin, R., Sif, S., Ikura, T., Ogryzko, V., Lane, W.S., Nakatani, Y., and Livingston, D.M. 2001. The p400 complex is an essential E1A transformation target. Cell 106: 297-307.

Harbour, J.W. and Dean, D.C. 2000. The Rb/E2F pathway: Expanding roles and emerging paradigms. Genes \& Dev. 14: 2393-2409.

Helin, K., Lees, J.A., Vidal, M., Dyson, N., Harlow, E., and Fattaey, A. 1992. A cDNA encoding a pRB-binding protein with properties of the transcription factor E2F. Cell 70: 337-350.

Hensey, C.E., Hong, F., Durfee, T., Qian, Y.W., Lee, E.Y., and Lee, W.H. 1994. Identification of discrete structural domains in the retinoblastoma protein. Amino-terminal domain is required for its oligomerization. J. Biol. Chem. 269: 1380-1387.

Ikeda, M.A. and Nevins, J.R. 1993. Identification of distinct roles for separate E1A domains in disruption of E2F complexes. Mol. Cell. Biol. 13: 7029-7035.

Kim, H.Y., Ahn, B.Y., and Cho, Y. 2001. Structural basis for the inactivation of retinoblastoma tumor suppressor by SV40 large T antigen. EMBO J. 20: 295-304.

Leclere, V., Huvent, I., Verwaerde, P., Cousin, C., and D'Halluin, J.C. 1993. Comparison between E1A gene from oncogenic and non-oncogenic adenoviruses in cellular transformation (Ad E1A conserved region). Arch. Virol. 132: 343-357.

Lee, J.O., Russo, A.A., and Pavletich, N.P. 1998. Structure of the retinoblastoma tumour-suppressor pocket domain bound to a peptide from HPV E7. Nature 391: 859-865.

Lee, C., Chang, J.H., Lee, H.S., and Cho, Y. 2002. Structural basis for the recognition of the $\mathrm{E} 2 \mathrm{~F}$ transactivation domain by the retinoblastoma tumor suppressor. Genes \& Dev. 16: 3199-3212.

Lehrmann, H. and Cotten, M. 1999. Characterization of CELO virus proteins that modulate the pRb/E2F pathway. J. Virol. 73: 6517-6525.
Li, Y., Graham, C., Lacy, S., Duncan, A.M., and Whyte, P. 1993. The adenovirus E1A-associated $130-\mathrm{kD}$ protein is encoded by a member of the retinoblastoma gene family and physically interacts with cyclins A and E. Genes \& Dev. 7: 2366-2377.

Lilyestrom, W., Klein, M.G., Zhang, R., Joachimiak, A., and Chen, X.S. 2006. Crystal structure of SV40 large T-antigen bound to p53: Interplay between a viral oncoprotein and a cellular tumor suppressor. Genes \& Dev. 20: 2373-2382.

Liu, X. and Marmorstein, R. 2006. When viral oncoprotein meets tumor suppressor: A structural view. Genes \& Dev. 20: 2332-2337.

Liu, X., Clements, A., Zhao, K., and Marmorstein, R. 2006. Structure of the human papillomavirus E7 oncoprotein and its mechanism for inactivation of the retinoblastoma tumor suppressor. J. Biol. Chem. 281: $578-586$.

Loewenstein, P.M., Arackal, S., and Green, M. 2006. Mutational and functional analysis of an essential subdomain of the adenovirus E1A N-terminal transcription repression domain. Virology 351: 312-321.

Raychaudhuri, P., Bagchi, S., Devoto, S.H., Kraus, V.B., Moran, E., and Nevins, J.R. 1991. Domains of the adenovirus E1A protein required for oncogenic activity are also required for dissociation of E2F transcription factor complexes. Genes \& Dev. 5: 1200-1211.

Rubin, S.M., Gall, A.L., Zheng, N., and Pavletich, N.P. 2005. Structure of the Rb C-terminal domain bound to E2F1-DP1: A mechanism for phosphorylation-induced E2F release. Cell 123: 1093-1106.

Schaeper, U., Boyd, J.M., Verma, S., Uhlmann, E., Subramanian, T., and Chinnadurai, G. 1995. Molecular cloning and characterization of a cellular phosphoprotein that interacts with a conserved C-terminal domain of adenovirus E1A involved in negative modulation of oncogenic transformation. Proc. Nat1. Acad. Sci. 92: 10467-10471.

Trouche, D. and Kouzarides, T. 1996. E2F1 and E1A(12S) have a homologous activation domain regulated by RB and CBP. Proc. Natl. Acad. Sci. 93: 1439-1442.

Wang, H.G., Rikitake, Y., Carter, M.C., Yaciuk, P., Abraham, S.E., Zerler, B., and Moran, E. 1993. Identification of specific adenovirus E1A Nterminal residues critical to the binding of cellular proteins and to the control of cell growth. J. Virol. 67: 476-488.

Whyte, P., Buchkovich, K.J., Horowitz, J.M., Friend, S.H., Raybuck, M., Weinberg, R.A., and Harlow, E. 1988. Association between an oncogene and an anti-oncogene: The adenovirus E1A proteins bind to the retinoblastoma gene product. Nature 334: 124-129.

Wong, H.K. and Ziff, E.B. 1994. Complementary functions of E1a conserved region 1 cooperate with conserved region 3 to activate adenovirus serotype 5 early promoters. J. Virol. 68: 4910-4920.

Xiao, B., Spencer, J., Clements, A., Ali-Khan, N., Mittnacht, S., Broceno, C., Burghammer, M., Perrakis, A., Marmorstein, R., and Gamblin, S.J. 2003. Crystal structure of the retinoblastoma tumor suppressor protein bound to E2F and the molecular basis of its regulation. Proc. Nat1. Acad. Sci. 100: 2363-2368. 


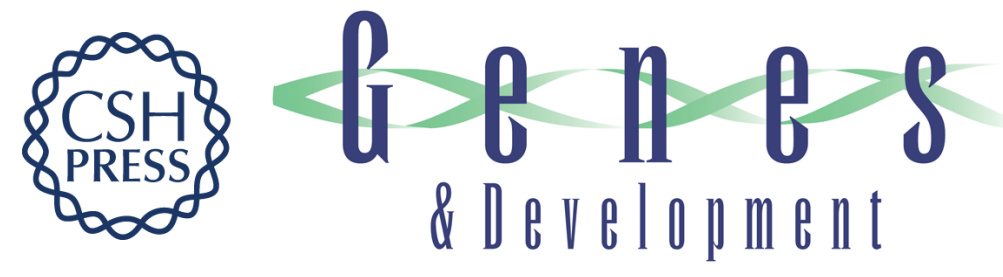

\section{Structure of the retinoblastoma protein bound to adenovirus E1A reveals the molecular basis for viral oncoprotein inactivation of a tumor suppressor}

Xin Liu and Ronen Marmorstein

Genes Dev. 2007, 21:

Access the most recent version at doi:10.1101/gad.1590607

Supplemental http://genesdev.cshlp.org/content/suppl/2007/10/18/21.21.2711.DC1

Material

References This article cites 32 articles, 20 of which can be accessed free at:

http://genesdev.cshlp.org/content/21/21/2711.full.html\#ref-list-1

License

Email Alerting Receive free email alerts when new articles cite this article - sign up in the box at the top

Service right corner of the article or click here.

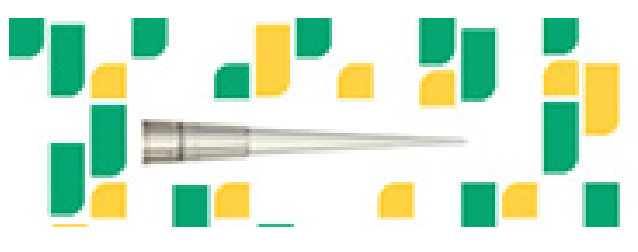

Focused on your science. 